\title{
THE GLOBAL TROPICAL MOORED BUOY ARRAY
}

\author{
M. J. McPhaden ${ }^{(1)}$, K. Ando ${ }^{(2)}$, B. Bourlès ${ }^{(3)}$, H. P. Freitag ${ }^{(1)}$, R. Lumpkin ${ }^{(4)}$, Y. Masumoto ${ }^{(2)}$, V. S. N. Murty ${ }^{(5)}$, \\ P. Nobre ${ }^{(6)}$, M. Ravichandran ${ }^{(7)}$, J. $_{\text {Vialard }}^{(8)}$, D. Vousden $^{(9)}$, W. Yu ${ }^{(10)}$ \\ (1) NOAA (National Oceanic and Atmospheric Administration)/Pacific Marine Environmental Laboratory, \\ 7600 Sand Point Way N.E. Seattle, WA 98115-6349, USA, Email: michael.j.mcphaden@noaa.gov \\ (2) Research Institute for Global Change, Japan Agency for Marine-Earth Science and Technology, \\ 2-15 Natsushima-cho,Yokosuka 237-0061,Japan,Email:andouk@jamstec.go.jp; masumoto@eps.s.u-tokyo.ac.jp \\ ${ }^{(3)}$ Institut de recherche pour le développement/Laboratoire d'Études en Géophysique et Océanographie Spatiale, \\ Cotonou, Benin, Email: Bernard.Bourles@ird.fr \\ (4) NOAA (National Oceanic and Atmospheric Administration)/Atlantic Oceanographic and Meteorological Laboratory, \\ 4301 Rickenbacker Causeway, Miami, FL 33149, USA, Email: Rick.Lumpkin@noaa.gov \\ ${ }^{(5)}$ National Institute of Oceanography, Regional Center, 176, Lawsons Bay Colony, Visakhapatnam - 530017 India, \\ Email:vsnmurty@nio.org \\ ${ }^{(6)}$ Instituto Nacional de Pesquisas Espaciais/Centro de Previsão de Tempo e Estudos Climáticos, \\ 12630-000, Cachoeira Paulista, São Paolo, Brasil,Email: pnobre@cptec.inpe.br \\ (7) Indian National Center for Ocean Information Services, P.B. No. 21, Ocean Valley, Gajularamaram, \\ IDA Jeedimetla, Hyderabad 500 055, India, Email: ravi@incois.gov.in \\ ${ }^{(8)}$ Institut de Recherche pour le Développement/Laboratoire d'Océanographie et du Climat: Expérimentation et \\ Approches Numériques, Boîte 100 - 4, place Jussieu 75252 PARIS Cedex 05, France, Email: vialardj@ nio.org \\ (9) Agulhas and Somali Current Large Marine Ecosystems Project, Grahamstown, South Africa, \\ Email: david.vousden@asclme.org \\ ${ }^{(10)}$ First Institute of Oceanography, State Oceanic Administration, 6 Xianxialing Road, Qingdao 266061, P.R. China, \\ Email: wdyu@fio.org.cn
}

\begin{abstract}
This paper describes the Global Tropical Moored Buoy Array (GTMBA), which is a multi-national effort to provide data in real time for climate research and forecasting. Components of the global array include the Tropical Atmosphere Ocean/Triangle Trans-Ocean Buoy Network (TAO/TRITON) in the Pacific, the Prediction and Research Moored Array in the Tropical Atlantic (PIRATA), and the Research Moored Array for African-Asian-Australian Monsoon Analysis and Prediction (RAMA) in the Indian Ocean. The phenomena of primary interest span intraseasonal-todecadal and longer timescales, including:
\end{abstract}

- El Niño/Southern Oscillation and its decadal modulation in the Pacific

- The meridional gradient mode and equatorial warm events in the Atlantic

- The Indian Ocean Dipole

- The mean seasonal cycle, including the Asian, African, Australian, and American monsoons

- The intraseasonal Madden-Julian Oscillation, which originates in the Indian Ocean but affects all three ocean basins

- Trends that may be related to global warming

Sustained, systematic and comprehensive observations are necessary to advance knowledge of critical processes that govern climate dynamics originating in the tropics. Observations are also needed to develop, initialize, and validate climate forecast models that can be used for advance warning of natural hazards and for many other societal benefits. A global tropical perspective is required not only because of the range and complexity of tropical phenomena that affect the climate system, but also because of basin-to-basin interactions that affect the evolution of climatic fluctuations. This paper reviews expansions and enhancements of moored buoy measurement efforts in the tropics since the October 1999 OceanObs'99 Conference in San Rafael, France. We will also highlight major scientific advances enabled by the Global Tropical Moored Buoy Array over the past 10 years.

\section{INTRODUCTION}

The tropics constitute a key region of the Earth's climate system. They experience the highest solar irradiance on the planet and export heat to higher latitudes through complex circulations in the ocean and atmosphere. Intense insolation also leads to the highest open ocean sea surface temperatures (SSTs) in tropics. These high SSTs contribute to vigorous oceanatmosphere interactions that affect regional patterns of precipitation on intraseasonal-to-decadal timescales. Atmospheric heating associated with these patterns of precipitation energize teleconnections to higher latitudes that affect climate worldwide. Phenomena of significant climatic consequence include El Niño/Southern Oscillation (ENSO) and its decadal modulation; the 
meridional gradient mode and equatorial warm events in the Atlantic; the Indian Ocean Dipole and the intraseasonal Madden-Julian Oscillation; the mean seasonal cycle and monsoon circulations; and decadal timescale trends that may be related to global warming.
The tropics are also the spawning ground for hurricanes, typhoons, and cyclones whose statistics (intensity, frequency, and spatial distribution) are strongly influenced by intraseasonal-to-decadal timescale climate variations.
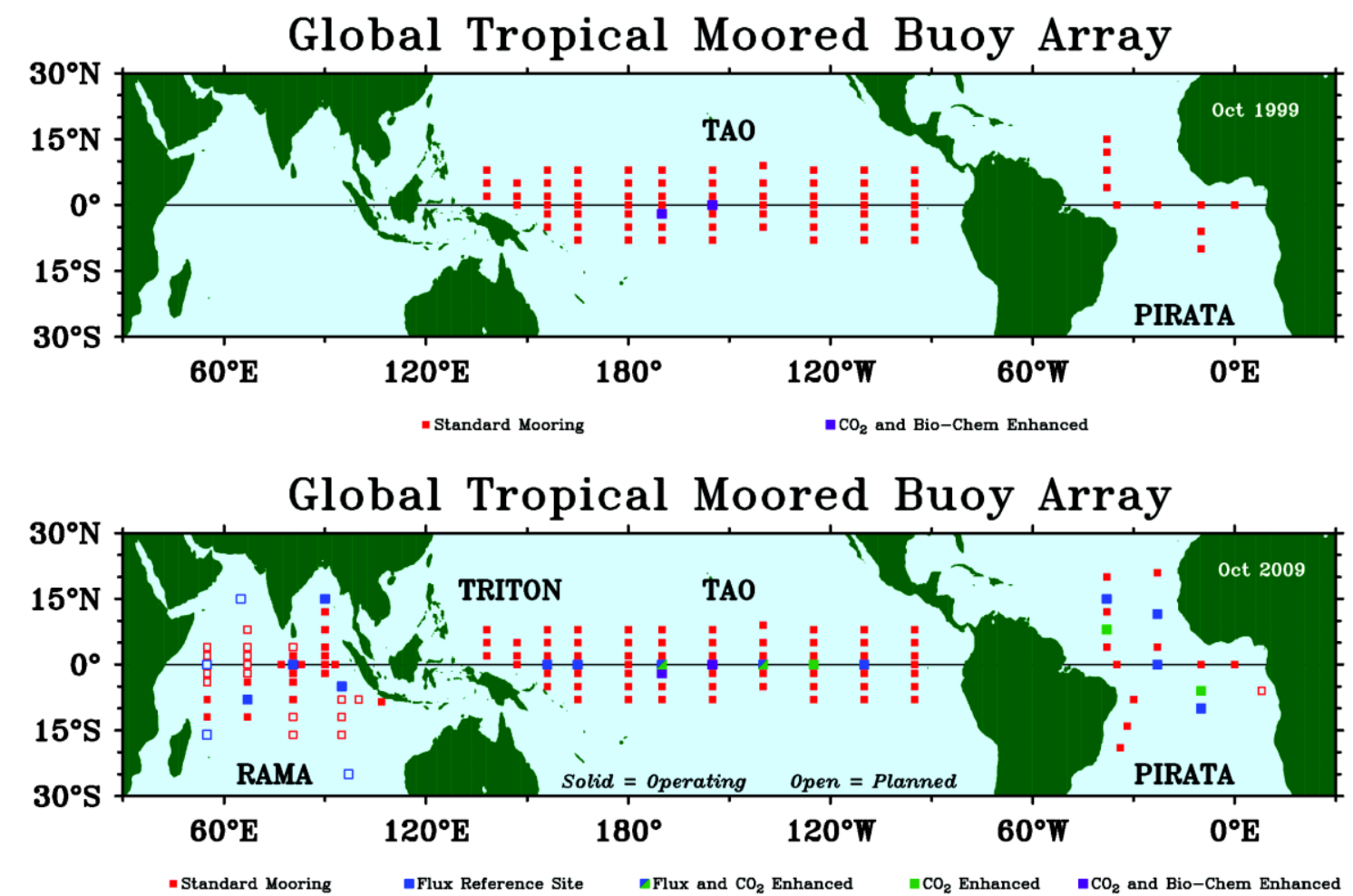

Figure 1. The Global tropical Moored Buoy Array in October 1999 (top) and October 2009 (bottom).

Sustained, systematic, and comprehensive observations are necessary to advance knowledge of critical processes that govern climate dynamics originating in the tropics. Observations are also needed to develop, initialize, and validate climate forecast models on intraseasonal-to-decadal timescales. To address these observational needs, moored buoy observing systems have been developed in all three tropical Oceans: TAO/TRITON in the Pacific, PIRATA in the Atlantic, and RAMA in the Indian Ocean. Together these arrays make up the Global Tropical Moored Buoy Array (Fig. 1). The purpose of this paper is to describe progress in implementing the GTMBA and the scientific advances it has enabled since the October 1999 OceanObs'99 Meeting in San Rafael, France.

\section{THE GLOBAL TROPICAL MOORED BUOY ARRAY (GTMBA)}

In this section we describe some general features of the GTMBA, followed by specific developments and selected science highlights for each ocean basin. TAO/TRITON, PIRATA, and RAMA have been designed and implemented within the context of the
Global Ocean Observing System (GOOS) and Global Climate Observing System (GCOS). The arrays are intended to provide measurements that uniquely complement other satellite and in situ components of these global observing systems. Numerical model observing system simulation experiments have been conducted to optimize the specific design of the moored arrays within the broad framework of the overall global ocean and climate observing systems.

The GTMBA is built primarily around Autonomous Temperature Line Acquisition System (ATLAS) moorings designed by NOAA's (National Oceanic and Atmospheric Administration) Pacific Marine Environmental Laboratory (PMEL) and Triangle Trans Ocean Buoy Network (TRITON) moorings designed by the Japan Agency for Marine-Earth Science and Technology (JAMSTEC). These surface moorings have special attributes that make them a valuable technology for tropical climate studies. In particular: 1) they can be instrumented to measure both upper ocean and surface meteorological variables involved in ocean-atmosphere interactions; 2) they provide time series measurements at fine temporal resolution (minutes to hours) to resolve 
high-frequency oceanic and atmospheric fluctuations that would otherwise be aliased into the lowerfrequency climate signals of primary interest; 3) they can be deployed and maintained on a fixed grid of stations so that measurements do not convolve variability in time and space.

Some ATLAS and TRITON moorings are more heavily instrumented for high-precision estimates of momentum, heat, and moisture fluxes across the air-sea interface. These "Flux Reference Site" moorings also have higher vertical resolution temperature, salinity, and in some cases velocity measurements in the upper $140 \mathrm{~m}$ to better resolve variations in the mixed layer, barrier layer, and thermocline. Flux Reference Site moorings and other moorings instrumented with biogeochemical sensors are a contribution to the Ocean Sustained Interdisciplinary Time series Environment Observation System (OceanSITES; [1]).

An important attribute of GTMBA surface moorings is that data is transmitted to shore in real time via satellite, which ensures retrieval of data even if a mooring is lost. Real-time data transmission of GTMBA data is primarily through Service Argos. The data are posted daily and made freely available on the NOAA/Pacific Marine Environmental Laboratory GTMBA web site (http://www.pmel.noaa.gov/tao/global/global.html) as well as several web sites maintained by partner institutions around the world. Service Argos inserts the data on the Global Telecommunications System (GTS) several times a day, which makes them available for real-time operational weather, ocean, and climate forecasting.

Details about all the types of moorings used in the GTMBA, including Flux Reference Site, subsurface ADCP, and deep ocean moorings, can be found in the Appendix. Mooring sensor specifications (accuracy, resolution, range), sensor calibration procedures, and data quality control for both real-time and delayed mode data streams are available from websites maintained by PMEL

(http://www.pmel.noaa.gov/tao/proj_over/mooring.shtm 1),

\section{JAMSTEC}

(http://www.jamstec.go.jp/jamstec/TRITON/real_time/o verview.php/po.php

and http://www.jamstec.go.jp/iorgc/iomics/index.html), and India's National Institute of Oceanography (NIO) (http://www.nio.org/data_info/deep-sea_mooring/oosdeep-sea-currentmeter-moorings.htm). A basin by basin description of the GTMBA follows.

\subsection{TAO/TRITON}

The TAO/TRITON array was developed over the 10year (1985-94) Tropical Ocean Global Atmosphere (TOGA) program for improved detection, understanding, and prediction of ENSO [2]. The array spans one-third the circumference of the globe at the equator and consists of 67 surface mooring (ATLAS and TRITON) plus five subsurface ADCP moorings. It was fully in place to capture the evolution of the 1997-98 El Niño, the strongest of the 20th century [3]. The array, originally called TAO, was renamed TAO/TRITON on 1 January 2000 with the introduction of JAMSTEC TRITON moorings at 12 locations in the western Pacific [4]

Beginning in 2005, existing moorings at five locations near the equator were upgraded to Flux Reference Sites (Fig. 1b), consistent with the recommendations of OceanObs'99 [5]. OceanObs'99 also called for a comprehensive TAO salinity measurement program in anticipation of NASA Aquarius and European Soil Moisture and Ocean Salinity (SMOS) surface salinity satellite missions [4]. Likewise, more salinity data were required in the tropical Pacific for climate research, for ocean state estimation, and for ENSO forecasting [6]. TRITON moorings included surface and subsurface salinity in the upper $750 \mathrm{~m}$ as part of its standard measurement suite [7], but salinity was a standard measurement on only subset of ATLAS moorings. Thus, PMEL began installing sea surface salinity (SSS) sensors on 55 ATLAS moorings of the TAO array in 2006 and by early 2008 the array was complete. Additional subsurface salinity measurements were included on all TAO Flux Reference Site moorings.

TAO/TRITON data have been used in over 600 refereed journal publications since its inception in 1985. Over half of these (341) have appeared since 2000. Recent scientific highlights include observational verification of the "Recharge Oscillator" theory for ENSO, which provided a formal mathematical framework for the hypothesis that a build up of excess warm water in the equatorial band is a necessary precondition for the development of El Niño events [8]. TAO/TRITON has been the dominant source of upper ocean temperature data near the equator over the past 25 years. The data show that depth average temperature in the upper $300 \mathrm{~m}$, an index for upper ocean heat content, leads Niño3.4 SST typically by 1-3 seasons (Fig. 2). A buildup of heat content at the end of this record, followed by rising Niño3.4 SSTs, indicates development of the current 2009 El Niño event. This relationship between upper ocean heat content and SST not only validates recharge oscillator theory, but also highlights 
Depth Averaged Temperature Anomalies $(0 / 300 \mathrm{~m})$ and NINO 3.4 SST $\left(5^{\circ} \mathrm{N}-5^{\circ} \mathrm{S}, 120^{\circ} \mathrm{E}-80^{\circ} \mathrm{W}\right)$

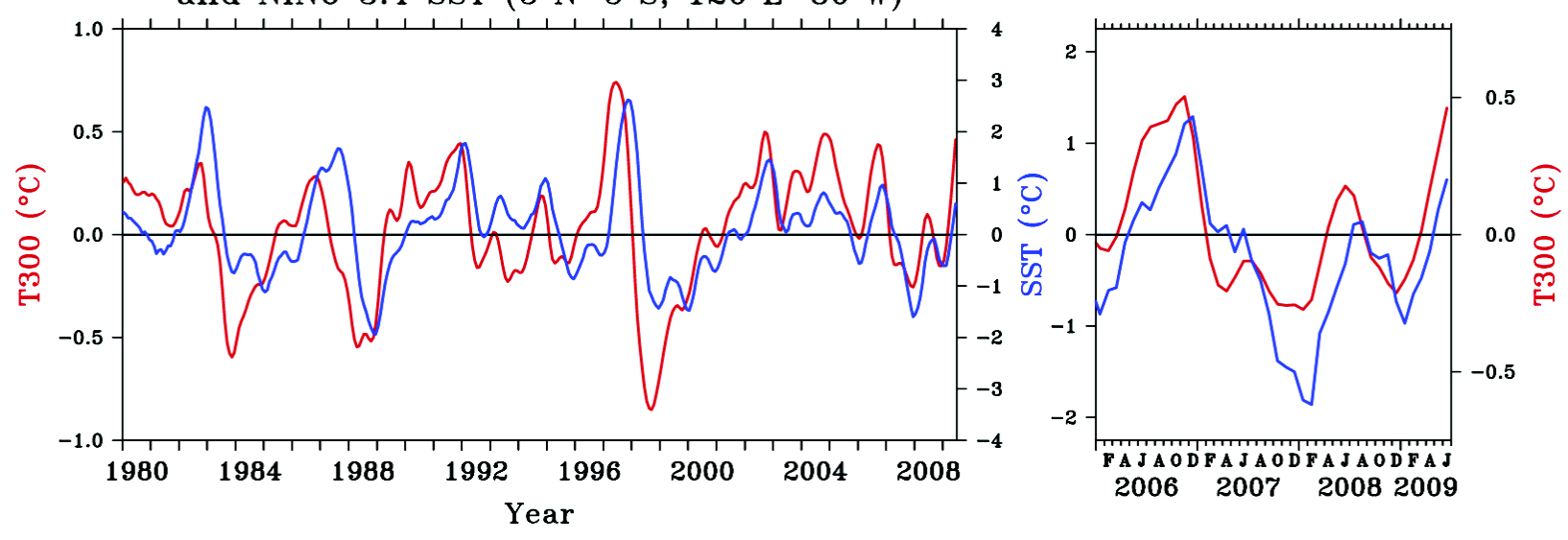

Figure 2. Depth-averaged temperature (T300) and Niño3.4 SST for January 1980 to June 2009. Monthly values in left panel have been smoothed with a 5-month running mean. The right panel shows the last three years of the record (unsmoothed) to highlight developing El Niño and La Niña conditions over 2006-09. Note the different scales for T300 and NINO3.4 SST in the two panels (after [93]).

the role of heat content as the primary source of predictability for ENSO. The simple relationship evident in Fig. 2 has also motivated the inclusion of upper ocean heat content as a predictor in some statistical ENSO forecast models [9] and [10], analogous to the assimilation of upper ocean temperature in dynamical ENSO forecast models [11].

TAO/TRITON data has also provided the observational underpinning for the concept of "state dependent noise forcing." It is well known that high-frequency zonal wind fluctuations can significantly affect the evolution of ENSO events [3] and [12]. However, analysis of TAO/TRITON data revealed that the phase of ENSO also influences the statistics of high-frequency wind forcing [13]. During El Niños, for example, westerly wind bursts tend to be stronger, more numerous, and extend further east along the equator than during $\mathrm{La}$ Niñas. This feedback between low frequency seasonalto-interannual timescale variations and high-frequency weather noise increases the strength of the coupling between the ocean and the atmosphere and the amplitude range of ENSO cycle variations [14].

El Niños of the 21st century have been characterized by SST anomalies along the equator that are largest near the international date line [15], [16] and [17]. These events have been termed "date line" [18] or "modoki" [19] El Niños. This class of El Niños has different climate impacts than those with largest anomalies in the eastern Pacific [20]. Ocean-atmosphere interactions that

\footnotetext{
1 "pseudo" in Japanese.
}

maintain well-developed trades in the eastern equatorial Pacific contribute to the concentration of largest SSTs in the central Pacific [21], [22] and [23]. What factors ultimately select for development of El Niños with largest SST anomalies in the eastern vs. central Pacific, though, are not known.

TAO/TRITON data are routinely used in ocean state estimation [24] and [25], operational ocean analyses [26], operational atmospheric analyses and reanalyses, and ENSO forecasting [27] and [28]. ENSO forecasting is an inexact science and there are many challenges to improving model forecast skill [10]. Nonetheless, TAO/TRITON data provide a key constraint on initial conditions for seasonal model forecasts at many centers around the world, such as the National Centers for Environmental Prediction (NCEP), the European Center for Medium Range Forecasting (ECMWF), the Japan Meteorological Agency (JMA), and the Australian Bureau of Meteorology (BOM) [29]. TAO/TRITON data have also been used extensively for model validation [30], [31] and [22] and for satellite validation of surface winds [32], [33] and [34], SST [35], [36] and [37], rainfall [38] and [39], and shortwave radiation [40] and [41].

TAO/TRITON is presently operated as a partnership between JAMSTEC and NOAA. Each partner provides mooring equipment and ship time under the terms of a Memorandum of Understanding between the two agencies. In 2002, the NOAA Administrator mandated transfer of TAO management responsibility from research at PMEL to operations at the National Data Buoy Center (NDBC), which is part of the National 
Weather Service. Transfer was initiated in 2005 and its progress will be described in Sect. 4.

\subsection{PIRATA}

PIRATA was designed for the purpose of improving our understanding and ability to predict ocean-atmosphere interactions that affect the regional patterns of climate variability in the tropical Atlantic basin [48]). A central focus was on variations in the Intertropical Convergence Zone (ITCZ) and the West African monsoon, which affect seasonal rainfall in Africa and northeastern Brazil as well as hurricane activity in the West Indies and the U.S. The program was originally launched as the "Pilot Research Moored Array in the Tropical Atlantic" with the deployment of two ATLAS moorings in September 1997 [42]. The core array of 10 moorings was installed by early 1999 (Fig. 1a) and an ADCP mooring was added at $0^{\circ}, 23^{\circ} \mathrm{W}$ in 2001 . The array is maintained via a partnership between NOAA/PMEL in the U.S., the French Institut de Recherche pour le Développement (IRD) and Météo-France, and the Instituto Nacional de Pesquisas Espaciais (INPE) and Diretoria de Hidrogafia e Navegacão (DHN) in Brazil.

It was realized that the initial PIRATA design was limited in geographic scope and therefore scientific utility. Thus, INPE initiated a three-mooring "Southwest Extension" in 2005 and the NOAA/Atlantic Oceanographic and Meteorological Laboratory initiated a four-mooring "Northwest Extension" in 2006. These extensions are complete and ongoing. South Africa sponsored a one-year "Southeast Extension" in 200607, though this site was not continued. Thus, the array expanded from 10 to 17 permanent sites between 1999 and 2007. Also, beginning in 2006, Flux Reference Sites were established in the core array at $15^{\circ} \mathrm{N}$, $35^{\circ} \mathrm{W} ; 0^{\circ}, 23^{\circ} \mathrm{W} ; 10^{\circ} \mathrm{S}, 10^{\circ} \mathrm{W}$ and in the Northeast Extension at $11.5^{\circ} \mathrm{N}, 23^{\circ} \mathrm{W}$.

Significant scientific progress has been enabled by PIRATA in the past 10 years [43]. Advances include a definition of the factors responsible for the mean seasonal cycles of SST and SSS [44], [45] and [46]. Studies have benefited from accurate surface heat and moisture fluxes estimated from high temporal resolution mooring data. In the SST balance, latent heat flux and shortwave radiation are important at all latitudes, though within a few degrees of the equator oceanic processes involving advection and vertical mixing become prominent. Variations north of the equator are strongly influenced by meridional seasonal migrations of the ITCZ, which are associated with large wind, latent heat, shortwave radiation, and precipitation changes. Thick barrier layers in the tropical north Atlantic play a significant role in insulating the surface layer from turbulent mixing with the thermocline [47] and [48]. PIRATA data have also been valuable for defining Equatorial Undercurrent (EUC) transports [49], for analyzing seasonal variability of the EUC [50], and for validating model simulations [51].
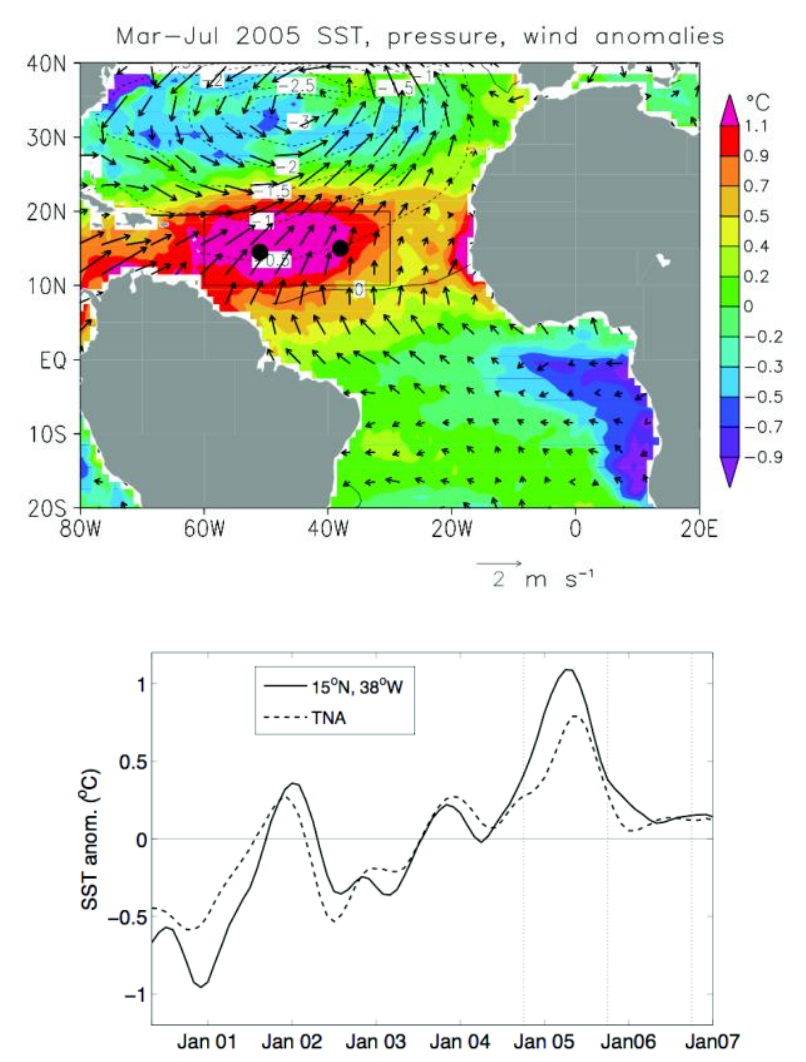

Figure 3. (top) Anomalies of surface wind (vectors), SST (color shading), and pressure (contours) for March-June 2005. (bottom) SST anomaly times series for 1999-2007 from the PIRATA mooring at $15^{\circ} \mathrm{N}$, $35^{\circ} \mathrm{W}$ (solid line) and for the Tropical North Atlantic (TNA) box shown in the top panel (dashed line) (from [52]).

The tropical Atlantic has witnessed substantial interannual variability during the past 10 years associated with equatorial warm events and meridional gradient mode fluctuations. For example, record high SSTs were observed in the tropical north Atlantic in 2005 , coincident with the most active hurricane season on record. This was followed in 2006 by a near-normal year for both SST and hurricane activity. PIRATA data have been very influential in identifying the causes of the observed SST variations in the tropical north Atlantic during this period (Fig. 3; [52] and [48]) even though there is debate about the precise role they play in hurricane activity [53]. Year-to-year swings in tropical north Atlantic SST appear to be principally related to wind-evaporation-SST feedbacks [54] with contributions from shortwave radiation and horizontal advection. The role of Saharan dust as a primary cause of interannual variations in north tropical Atlantic SST as recently hypothesized [55] does not appear to be as 
significant as that for latent heat loss based on PIRATA data [56]. These interannual variations are superimposed on a warming trend in the tropical North Atlantic (Fig. 3) that may be related to anthropogenic greenhouse gas forcing, variations in the Atlantic Multidecadal Oscillation, and/or reductions in Saharan dust [57].

PIRATA data have contributed to definition of a new mode of tropical Atlantic variability similar to equatorial warm events but with a peak in NovemberDecember [58]. This new mode develops in association with an anomalous intensification of the equatorial easterlies, which causes upwelling and cooling in the Gulf of Guinea. Rainfall in the eastern basin on interannual timescales is significantly affected by this mode, which can also lead to development of a meridional mode during the following March-April.

As with TAO/TRITON, PIRATA data are used routinely in ocean state estimation, operational oceanic and atmospheric analyses, and atmospheric reanalyses [43]. They are also used in forecasting of tropical Atlantic climate variability on seasonal timescales [59]. Seasonal forecasting is not as advanced and predictability is more limited at present in the tropical Atlantic compared to the Pacific for ENSO. This may result from a variety of factors. For instance, interannual SST anomalies are smaller and the effects of ocean dynamics on SST are less pronounced in the tropical Atlantic than in the Pacific [60]. There are also competing influences from outside the basin (e.g., from ENSO in the Pacific and from higher latitudes in the North Atlantic) that can interfere with variability arising intrinsic to the tropical Atlantic [61] and [62]. Finally, there are large systematic errors in coupled oceanatmosphere models of the Atlantic that lead to significant biases in simulated climate variability [63].

Despite limited predictability on seasonal timescales, PIRATA data have been valuable in constraining seasonal forecast initial conditions, in assessing forecast model skill, and in guiding forecast model improvements [64 and 51]. Current users of the data for seasonal forecasting include institutions such as Tempo e Estudos Climáticos/INPE (CPTEC/INPE), MétéoFrance, NCEP, and ECMWF. PIRATA data are also used extensively for satellite validation, often in conjunction with TAO/TRITON data [38], [34] and [41]. Given that PIRATA has matured beyond a "Pilot" program over the past 12 years, the PIRATA Scientific Steering Group (SSG) redefined the PIRATA acronym in 2008 to be "Prediction and Research Moored Array in the Tropical Atlantic" [43].

Partners in the U.S., France, and Brazil have committed to support PIRATA through a formal MOU. Under the terms of this MOU, the U.S. provides most of the mooring equipment and ship time for the Northwest extension, while France and Brazil provide ship time for most of the moorings network. A PIRATA Resource Board, made up of members from agencies supporting the program in each country, is charged with finding the resources required to meet the program's scientific objectives as defined by the SSG. This organizational structure has served PIRATA well, contributing to technology transfer, capacity building, and scientific productivity among the partner institutions.

Despite progress in the past 10 years, gaps in PIRATA still remain. In particular, the Southeast Extension Site needs to be reoccupied and sustained. Also, a future extension of PIRATA into the south central tropical Atlantic (i.e., between $5^{\circ}-15^{\circ} \mathrm{S}, 10^{\circ}-30^{\circ} \mathrm{W}$ ) would fill a gap that presently exists there (Fig. 1b). Finally, a new Flux Reference Site in the Southwest Extension would complement others already established in the array.

\subsection{RAMA}

The Indian Ocean is unique among the three tropical ocean basins in that it is blocked at $25^{\circ} \mathrm{N}$ by the Asian land mass. Seasonal heating and cooling of the land sets the stage for dramatic monsoon wind reversals, strong ocean-atmosphere interactions, and intense seasonal rains over the Indian subcontinent, Southeast Asia, East Africa, and Australia. Recurrence of these monsoon rains is critical to agricultural production that supports a third of the world's population. Embedded within the monsoon system is range of interacting phenomena spanning timescales from synoptic weather events to decadal trends. Of particular interest are intense tropical cyclones, intraseasonal variations associated with the Madden-Julian Oscillation (MJO), interannual variations associated with ENSO and the Indian Ocean Dipole (IOD), and warming trends since the 1970s that may be related to anthropogenic greenhouse gas forcing [65]. The Indian Ocean also remotely influences the evolution of ENSO, the North Atlantic Oscillation (NAO), North American weather, and hurricane activity in the Atlantic and Pacific. Despite its importance in the regional and global climate system, though, the Indian Ocean is the most poorly observed and least well understood of the three tropical oceans.

RAMA was initiated in 2004 for improved description, understanding, and prediction of the east Africa, Asian and Australian monsoon systems [66]. It was designed by the CLIVAR/GOOS Indian Ocean Panel as a contribution to the Indian Ocean Observing System (IndOOS; [67] and [68]), building upon the success of pioneering regional-scale arrays initiated by $\mathrm{NIO}$ and JAMSTEC in 2000 [69] and [70]. RAMA consists of 46 moorings spanning the width of the Indian Ocean between $15^{\circ} \mathrm{N}$ and $26^{\circ} \mathrm{S}$ (Fig. 1b). Most of the moorings (38) are either ATLAS or TRITON, eight of which are enhanced as Flux Reference Site moorings. Four ADCP moorings are located on the equator and one off the coast of Java for direct measurements of ocean 
circulation. Three deep-ocean moorings (see appendix) collect data down to $4000 \mathrm{~m}$ along the equator. At present, 24 of the 46 sites have been occupied with support from the U.S., Japan, India, Indonesia, France, China and nine east African nations ${ }^{2}$ that makes up the Aguhlas and Somali Current Large Marine Ecosystem (ASCLME) program. We expect the array will be completed by 2012 . fluxes are important in generating IOD SST anomalies [76]. In the Seychelles Chagos Thermocline Ridge (SCTR) region, pronounced intraseasonal heat fluxes associated with the MJO lead to large SST cooling events, especially in boreal winter. Data from a RAMA mooring at $8^{\circ} \mathrm{S}, 67^{\circ} \mathrm{E}$ during November 2007-February 2008 captured two MJO events that resulted in strong intraseasonal SST variations $\left(1.5\right.$ to $2^{\circ} \mathrm{C}$ in 20 days $)$. At

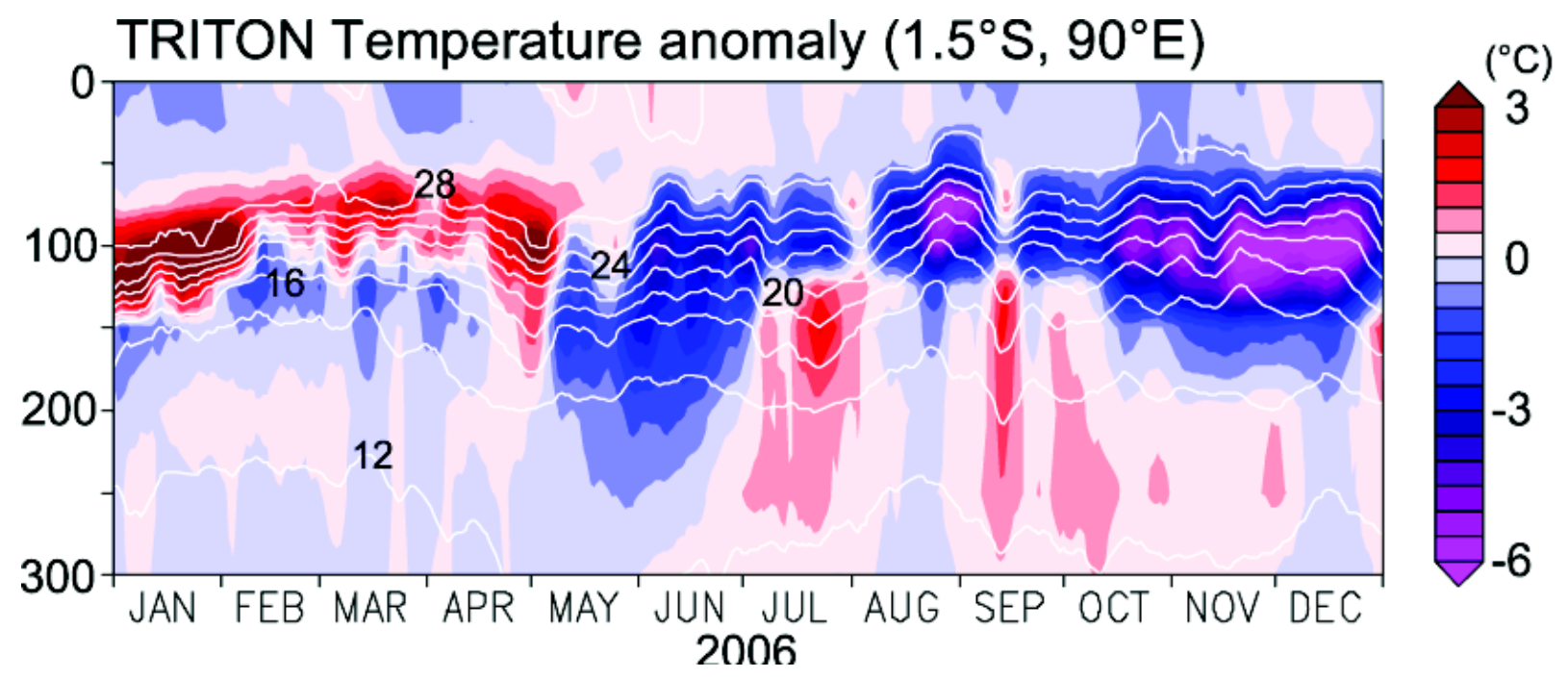

Figure 4. Subsurface temperature (contours) and temperature anomalies (color shading) from the TRITON mooring at $1.5^{\circ} \mathrm{S}, 95^{\circ} \mathrm{E}$ for 2006 (from [74]).

RAMA, even in the initial stages of development, is providing valuable data for describing and understanding variability in the Indian Ocean. For example, a pronounced semiannual cycle in upper-ocean temperature, salinity, and zonal velocity is evident in the first three years of data from near-equatorial moorings at $90^{\circ} \mathrm{E}$ [71]. The semiannual velocity variations are referred to as Wyrtki Jets and their zonal mass transports are largely governed by wind-forced linear dynamics [72]. They are also strongly modulated on 3050-day intraseasonal timescales related to the MJO [70]. Variations in meridional velocity on the equator, in contrast, are dominated by higher frequency 10-20-day period oscillations, which are evident not only in the upper $400 \mathrm{~m}$ but also at depths greater than $2000 \mathrm{~m}$ [73] and [74]. These oscillations are wind forced mixed Rossby-gravity waves [69].

RAMA data indicate that subsurface temperature variations lead those at the surface by a season near the equator in eastern basin (Fig. 4), suggesting that anomalies in upper-ocean heat content may be a source of predictability for the IOD as in the Pacific for ENSO [75]. In addition, zonal advection and surface heat

2 Kenya, Tanzania, Mozambique, South Africa, Madagascar, Mauritius, Seychelles, Somalia, and Comoros. the mooring site, atmospheric fluxes dominated the upper ocean heat balance at the MJO timescale, with the net surface heat flux into the ocean decreasing from an average $105 \mathrm{~W} \mathrm{~m}^{-2}$ during suppressed phases to $15 \mathrm{~W}$ $\mathrm{m}^{-2}$ during active phases of the MJO [77]. RAMA data were also used to observe the oceanic response to cyclone Nargis, which made landfall in Myanmar on 2 May 2008 and was the deadliest natural disaster to affect the Indian Ocean region since the 26 December 2004 tsunami. Intense ocean mixing and significant turbulent heat loss from the ocean surface $\left(\sim 600 \mathrm{~W} \mathrm{~m}^{-2}\right)$ occurred as Nargis passed near a RAMA buoy at $15^{\circ} \mathrm{N}$, $90^{\circ} \mathrm{E}$ in the Bay of Bengal [78].

There have been some successes in forecasting seasonal variability using coupled ocean-atmosphere models that include the Indian Ocean region [79], though the skill at present is lower than for ENSO in the Pacific. This lower skill may be related to model biases, weaker amplitude interannual climate anomalies, less inherent predictability, and/or a lack of ocean data for initialization. To the extent that data availability is a limitation, RAMA and other data from IndOOS should lead to improvements in forecast skill.

RAMA data have not yet been utilized widely in seasonal climate forecasting because the array is still not yet complete and records lengths are relatively short. However, the data have already found application with 
farmers in Australia who have used it to guide cropping strategies in the face of expected IOD-induced drought conditions [66]. Also, RAMA data are available on the GTS and incorporated into weather forecasts at operational centers. We can expect that as the array becomes fully implemented and monsoon forecast methodologies further advance, RAMA will provide a valuable data stream for the initialization and validation of climate prediction models.

Implementation of RAMA has proceeded through several bilateral agreements between agencies in partner nations ${ }^{3}$. In addition to these bilateral agreements, Indian Ocean GOOS has established an "IndOOS Resource Forum" which will provide an international framework to coordinate all resources committed to IndOOS in general and RAMA in particular. So far, NOAA has provided the bulk of the mooring equipment for RAMA (with additional contributions from India, Japan, and China) while nations in the region have provided the bulk of the ship time. Scientific oversight of RAMA is provided by the CLIVAR/GOOS Indian Ocean Panel.

\section{RELATION TO OTHER OBSERVING SYSTEM COMPONENTS}

As described in Section 2, the GTMBA is fully integrated in GOOS and GCOS. The GTMBA brings specific "value-added" benefits to the observing system beyond the moored time series data themselves, however. These benefits are described below.

Ships dedicated to servicing the moored buoy arrays typically repeat at intervals of six months to one year, since the design lifetime of ATLAS and TRITON moorings is one year. These cruises routinely collect standard shipboard data that accumulate as a valuable addition to the climate data base. Measurements include Conductivity-Temperature-Depth (CTD) station data and underway Acoustic Doppler Profiler (ADCP), thermosalinograph, $\mathrm{CO}_{2}$, and surface meteorological data [80], [81], [49] and [82]. Cruises to service mooring arrays also regularly deploy Argo floats and surface drifters in order to help maintain these components of GOOS.

\footnotetext{
3 These bilateral agreements are between NOAA and JAMSTEC; NOAA and the Indian Ministry of Earth Science (MoES); NOAA and Indonesia's Ministry of Marine Affairs and Fisheries (DKP); NOAA and the Agency for the Assessment and Application of Technology (BPPT); JAMSTEC and BPPT; and DKP and the Chinese State Oceanic Administration (SOA). Another bilateral agreement is presently under development between NOAA and ASCLME.
}

Although the moored arrays in each basin have been designed primarily to address questions regarding physical climate variability, biogeochemical sensors have also been added at several locations to provide time series measurements for studies of biological productivity and oceanic uptake of $\mathrm{CO}_{2}$. In 1999, there were two biogeochemical stations established on TAO moorings in the Pacific (Fig. 1a; [83]). Since 2003, additional multi-disciplinary ocean observatories have been established in the tropical Pacific and Atlantic (Fig. 1b) as a contribution to OceanSITES. Plans are also underway to instrument several RAMA moorings with biogeochemical sensors as a contribution to both OceanSITES and the Sustained Indian Ocean Biogeochemistry and Ecosystem Research (SIBER) program.

The GTMBA has also provided a long-term, large-scale context for short-duration, regionally focused processoriented field studies. These include the Eastern Pacific Investigation of Climate Processes (EPIC; [81] and [84]), the Tropical Atlantic Climate Experiment (TACE; [85]), the African Monsoon Multidisciplinary Analysis (AMMA; [86]) and its ocean component [87], the Mirai Indian Ocean cruise for the Study of MJO-convection Onset (MISMO; [88]) and Vasco-Cirene [89]. In turn, these process studies have provided opportunities to service GTMBA moorings, to test out new instrumentation for moored applications, and to assess mooring array design in view of process study findings.

\section{CHALLENGES}

The GTMBA has successfully enabled significant advances in climate research and forecasting over the past 25 years. Notwithstanding, there are challenges to its continued success in the future. We described these challenges briefly in this section.

\subsection{Ship Time}

Ship time is a critical resource for maintaining the arrays and specialized ships capable of deep-sea mooring operations are required. Such vessels are in high demand and short supply. Ideally, surface moorings should be recovered and redeployed once per year with service visits at six-month intervals for necessary repairs. This ideal is achieved only for the TAO portion of the TAO/TRITON array. Ship time for TAO, moreover, has been trending downward in the past few years due to reduced operating schedules in the NOAA fleet; similar downward pressure on JAMSTEC ship time for servicing TRITON moorings is also being felt. Servicing of PIRATA moorings in the Atlantic is roughly on a 12-month schedule using French, Brazilian and U.S. vessels. Data return in PIRATA has traditionally been $5-15 \%$ lower than in TAO/TRITON in part because of the less frequent servicing. It has been difficult in the start-up phase of RAMA to ensure 
regular cruises at even 12-month intervals. Partner nations in RAMA recognize that this is a problem and it is being addressed through a more structured planning process that involves coordination through the IndOOS Resource Forum.

\subsection{Vandalism and Piracy}

Vandalism by fishermen is the greatest source of equipment and data loss in all three ocean basins. Moored buoys act as fish aggregation devices (FADs) which attract fishermen. In working around buoys, fishermen may get their nets or long lines entangled in the mooring and then damage the moorings trying to extract their gear. Sometimes the damage is intentional as evident, for example, from bullet holes in buoy equipment and missing sensors and hardware that have been sawed off.

Symptomatic of problems with vandalism, significant TAO data dropouts have occurred during the development phase of the current El Niño because of damage from fishing boats in the eastern Pacific. This loss of data, aggravated by a reduction in ship time to service the array, has compromised our ability to accurately describe the evolution of the event and to predict its further evolution [90]. Fishing vandalism also leads to substantial data and equipment loss in the Atlantic (especially in the Gulf of Guinea) and in the Indian Ocean.

Outreach, enforcement, and engineering development are in principle three ways to deal with vandalism. Outreach, which has been attempted for 20 years, is ineffective because there are thousands of ships from many countries fishing the open tropical oceans, primarily for tuna, and it is not possible to reach them all. Moreover, it not clear in our experience that providing information to fishermen about the delicacy of instrumentation or value of the data has much impact on their fishing operations near moored buoys. Enforcement is essentially impossible given the requirements of identifying and successfully prosecuting violators.

Engineering solutions are the only practical approach and new mooring designs are presently being tested that may help mitigate some of the loss from vandalism. JAMSTEC engineers for example have developed an "iron-mask" instrument tower to protect the meteorological sensors against tampering. Initial tests in regions of high vandalism show increased data return with no serious degradation in data quality despite the fact that the iron mask is designed to partially shield the sensors. Likewise, PMEL has developed a "conehead" buoy to discourage vandalism. The buoy surface is very smooth to prevent boarding and contains no attachment points. Two conehead moorings were deployed without meteorological sensors in August 2008 at locations in
RAMA that had previously suffered heavy vandalism. They were recovered in September 2009 with nearly $100 \%$ data return. These conehead moorings were replaced in September 2009, but with the addition of a single low-profile meteorological sensor package to measure wind, air temperature, relative humidity, precipitation, and barometric pressure.

Piracy on the high seas is a new concern in the Indian Ocean. The recent increase in vessel hijackings by Somali pirates led, for example, to the curtailment of the November 2009 ASCLME cruise north of $10^{\circ} \mathrm{S}$ in the western basin. This cruise would have completed the $55^{\circ} \mathrm{E}$ RAMA line. Full implementation of RAMA will require that the piracy problem in the Indian Ocean be brought under control.

\subsection{Engineering Development}

Engineering is important not only for development of vandal-resistant mooring designs but also for ensuring mooring designs keep pace with advances in sensor technology, materials science, and data telemetry systems. Thus, PMEL has developed the concept of a "buoy in a box" for climate applications. The design involves a compact self-contained buoy hull, mooring line, and anchor resting on a pallet. The oceanographic measurement package consists of a profiler for temperature, conductivity, and other optional data. The profiler sinks to a prescribed depth, then crawls back up the mooring line extracting energy from mooring-line motion induced by surface gravity waves. The system self deploys after being slid off the pallet from a vessel that need only have a small crane or winch. Successful proof-of-concept deployments of this system have been made. Work is ongoing to ensure reliability over yearlong deployments and to incorporate meteorological sensors into the design. This mooring design, if proven to be robust and reliable, would have the beneficial effect of reducing the requirement for highly specialized research vessels to maintain the GTMBA.

\subsection{Institutional Challenges}

Like many other components of the global ocean observing system, TAO/TRITON, PIRATA, and RAMA have been designed and implemented by researchers. Sustaining these ocean-observing systems for the long term as part of GOOS and GCOS will be a challenge because they are resource intensive and because they require institutional support that transcends the professional lifetime of a particular research scientist or group of scientists. There are, however, few if any precedents for the research community to sustain successful ocean observing systems for climate over timescales of decades.

In the case of TAO, the transfer of management responsibility from PMEL to NDBC was supposed to address this issue. However, that transfer has not been a 
success as measured by cost, schedule, and performance. The transition from research to operations was originally planned to take three years (from 2005 to 2007), but it will end up taking 11 years to complete [91]. The reason is that the PMEL ATLAS mooring, a legacy system with customized electronics and ocean sensors, does not meet NDBC's operational requirements for measurement platforms to be based on all commercial-off-the-shelf (COTS) components. The equivalent COTS ATLAS mooring does not exist now and the National Weather Service estimates it will take until 2015 to design, test, certify, and produce such a system in sufficient numbers to maintain the array. In the meantime, annual TAO data return has declined from $>90 \%$ to $\sim 80 \%$ and operating costs have escalated much faster than inflation [91].

Climate observations must be managed within the context of an end-to-end system that includes data collection, modeling, forecasting, and the provision of climate information and services to society for practical applications. Climate observing systems also need to continually evolve as we learn more about climate variability and change and as advances in climate forecast models and data assimilation methodologies impose new demands on the observing system. Research plays a critical role in guiding the evolution of observing systems by establishing scientific priorities, by developing new measurement technologies to address those priorities, and by performing high level quality control through scientific analyses of the data. Thus, as both stakeholder and partner, the research community needs to be an active participant in the governance structure of climate observing systems in order to ensure they are cost-effectively operated, preserve data continuity and quality, are responsive to evolving measurement requirements, and adhere to climate observing system principles [92].

New institutional arrangements, such as the establishment of national climate services, may be one way to address the unique problems associated with developing, sustaining, and evolving climate observing systems in the oceans for the $21 \mathrm{st}$ century. In this regard, the third World Climate Conference, held in Geneva in September 2009, has called for the establishment of an international framework for climate services, including the ocean observations that support those services (http://www.wmo.int/wcc3). The alignment of climate services with the observations that underpin them provides a compelling logic for sustaining ocean observing systems. We therefore suggest adopting a principle that, whenever possible, ocean observing systems in support of climate be operated by organizations involved in providing climate services.

\section{RECOMMENDATIONS}

In the foregoing sections we have illustrated the value of moored time series measurements for climate forecasting and research and highlighted the unique niche they fill in GOOS and GCOS. Based on these considerations, we believe that the GTMBA forms an essential component of the ocean observing system for climate and that it is important to consolidate and build on advances made since OceanObs'99. In particular, we recommend the following priority actions for the coming decade:

- Stabilize and sustain TAO/TRITON for climate forecasting and research on seasonal, decadal, and longer timescales.

- Sustain PIRATA to support forecasting and research on tropical Atlantic climate variability; in addition, reoccupy the discontinued PIRATA Southeast Extension site, establish a Flux Reference Site in the PIRATA Southwest Extension, and fill the gap in the south central tropical Atlantic with a new extension.

- Complete and sustain RAMA to advance forecasting and research on the African-AsianAustralian monsoon, the Indian Ocean Dipole, and related phenomena.

- Sustain and expand the program of $\mathrm{CO}_{2}$ and other biogeochemical measurements in the GTMBA, especially in the Indian Ocean where no RAMA moorings have yet been equipped with biogeochemical sensors.

To achieve these goals, we further recommend participation of countries that have a stake in the success of the GTMBA but who are not at present involved in its maintenance.

\section{SUMMARY AND CONCLUSION}

The Global Tropical Moored Buoy array program, consisting of TAO/TRITON, PIRATA and RAMA, is an integral part of GOOS and GCOS. It provides valuable data to support climate forecasting and has stimulated fundamental advances in our understanding of the climate system. RAMA, initiated in 2004, is the most recent addition to the GTMBA. With its expected completion in 2012, the GTMBA will encircle the globe in the tropics. There are many challenges to successful maintenance of TAO/TRITON, PIRATA and RAMA, not the least of which is identifying new institutional arrangements that can cost-effectively sustain these arrays for the coming decades. However, sustaining and enhancing the GTMBA is a high priority because of its unique and essential role in support of climate forecasting and research. 


\section{Appendix: Mooring Technology used in the Global Tropical Moored Buoy Array Program}

Two main types of moorings are presently used in the GTMBA program: surface moorings and subsurface moorings. Most of the surface moorings are ATLAS moorings designed by PMEL. Measurements on the surface float include air temperature, relative humidity, wind velocity, downwelling shortwave radiation, and rain rate at heights of 3-4 m above mean sea level. Sea surface temperature and conductivity (which together yield salinity) are measured from the buoy at a nominal depth of $1 \mathrm{~m}$. Sensors on the mooring line measure ocean temperature (12 depths between $10 \mathrm{~m}$ and $500 \mathrm{~m}$ ) and pressure (at two depths). Conductivity is routinely measured at 4 depths (PIRATA) and 5 depths (RAMA) in the upper $120 \mathrm{~m}$. Mixed layer velocity (at $10 \mathrm{~m}$ depth) is included on all RAMA moorings and at Flux Reference Site moorings in PIRATA and TAO. Flux Reference Site moorings include sensors for downwelling longwave radiation, barometric pressure, and additional sensors in the upper $140 \mathrm{~m}$ of the ocean for finer vertical resolution measurements of temperature, salinity and velocity.

Daily averages of all data and several hourly samples per day of most meteorological variables are transmitted to shore in real time via Service Argos. These data are placed on the GTS for use in operational weather, climate, and ocean forecasting. Higher temporal resolution data (at 1- to 10-minute intervals in most cases) are internally recorded and available after mooring recovery.

JAMSTEC has contributed TRITON moorings to TAO/TRITON and RAMA. These are taut-line surface moorings designed to be functionally equivalent to ATLAS moorings in terms of sensor payloads, temporal resolution, and data accuracy. There are some differences (e.g., TRITON moorings are deployed with more salinity sensors and measurements are made to $750 \mathrm{~m}$ rather than $500 \mathrm{~m}$ ), but these differences do not affect comparability of the basic data sets. In 2008, JAMSTEC introduced the m-TRITON mooring as a replacement of the TRITON mooring in RAMA. The mTRITON is lower cost and easier to deploy than a TRITON mooring. The m-TRITON sensor and signal processing system are based on those for TRITON, but the mooring system itself is slack line rather than tautline. Slack line moorings allow for substantial vertical excursions of subsurface sensors due to variable currents and winds. Thus, all m-TRITON subsurface sensors are equipped to measure pressure so that the shape of the mooring line can be determined, after which temperature and salinity data can be interpolated to standard depths. Hourly averages of all TRITON and $\mathrm{m}$-TRITON data are transmitted to shore in real-time via Service Argos and placed on the GTS. Higher temporal resolution data (at 1- to 10-minute intervals in most cases) are internally recorded and available after mooring recovery.

The primary subsurface mooring systems involve an upward-looking ADCP mounted on a subsurface float at depths of $250-400 \mathrm{~m}$ depending on location. Velocity profiles are measured at hourly intervals with $8 \mathrm{~m}$ vertical resolution. These moorings are mostly concentrated near the equator where pure geostrophy breaks down and direct velocity measurements are required. ADCP data are internally recorded and available upon mooring recovery. The ADCP mooring array in TAO/TRITON maintained by the U.S. (NOAA) and Japan (JAMSTEC), in PIRATA by France (IRD) and Brazil (INPE), and in RAMA by Japan (JAMSTEC), Indian (MoES), the U.S. (NOAA), China (SOA), and Indonesia (DKP).

In addition to ADCP moorings, NIO maintains subsurface moorings in RAMA at three locations along the equator to monitor temperature, salinity, and current variations throughout the water column [73]. They have a subsurface float nominally at $100 \mathrm{~m}$ depth, below which six mechanical current meters are attached to the mooring line for velocity measurements down to a depth of approximately $4000 \mathrm{~m}$. Beginning in 2003, upwardpointing ADCPs similar to those used on the standard ADCP mooring were added to the near-surface float for additional velocity measurements. Data at 1-2-hour intervals are available from these moorings on recovery.

\section{REFERENCES}

1. Send, U. \& Co-Authors (2010). "OceanSITES" in these proceedings (Vol. 2), doi:10.5270/OceanObs09.cwp.79.

2. McPhaden, M.J., Busalacchi, A.J., Cheney, R., Donguy, J.R., Gage, K.S., Halpern, D., Ji, M., Julian, P., Meyers, G., Mitchum, G.T., Niiler, P.P., Picaut, J., Reynolds, R.W., Smith, N. \& Takeuchi, K. (1998). The Tropical Ocean-Global Atmosphere (TOGA) Observing System: A Decade of Progress. J. Geophys. Res., 103, 14,16914,240 .

3. McPhaden, M.J. (1999). Genesis and Evolution of the 1997-98 El Niño. Science, 283, 950-954.

4. McPhaden, M.J., Delcroix, T., Hanawa, K., Kuroda, Y., Meyers, G., Picaut, J. \& Swenson, M. (2001). The El Niño/Southern Oscillation (ENSO) Observing System. In: Observing the Ocean in the 21st Century. Australian Bureau of Meteorology, Melbourne, Australia, 231-246.

5. Send, U. Co-authors (2001). Oceanographic Timeseries Observatories. In: Observing the Ocean in the 21st Century. Australian Bureau of Meteorology, Melbourne, Australia, 376-390.

6. Maes, C., Picaut, J. \& Belamari, S. (2005). Importance of the Salinity Barrier Layer for the Buildup of El Niño, $J$. Climate, 18, 104-118. 
7. Ando K., Matsumoto, T., Nagahama, T., Ueki, I., Takatsuki, Y., \& Kuroda, Y. (2005). Drift Characteristics of a Moored Conductivity-Temperature Sensor and Correction of Salinity Data. J. Atmos. Oceanic Technol., 22, 282-291, doi:0.1175/JTECH1704.1.

8. Jin, F.F. (1997). An Equatorial Recharge Paradigm for ENSO. Part I: Conceptual Model, J. Atmos. Sci., 54, 811-829.

9. Clarke, A.J. \& Van Gorder, S. (2003). Improving El Niño Prediction Using a Space-Time Integration of IndoPacific Winds and Equatorial Pacific Upper Ocean Heat Content. Geophys. Res. Lett., 30(7), 1399 , doi:10.1029/2002GL016673.

10. McPhaden, M.J., Zhang, X., Hendon, H.H. \& Wheeler, M.C. (2006). Large Scale Dynamics and MJO Forcing of ENSO Variability. Geophys. Res. Lett., 33(16), L16702, doi:10.1029/2006GL026786.

11. Latif, M., Anderson, D., Barnett, T., Cane, M., Kleeman, R., Leetmaa, A., O'Brien, J., Rosati, A. \& Schneider, E. (1998). A Review of the Predictability and Prediction of ENSO. J. Geophys. Res., 103, 14,375-14,394.

12. Zavala-Garay, J., Zhang, C., Moore, A.M. \& Kleeman, R. (2005). The Linear Response of ENSO to the MaddenJulian Oscillation, J. Climate, 18, 2441-2459.

13. Eisenman, I., Yu, L. \& Tziperman, E. (2005). Westerly Wind Bursts: ENSO's Tail Rather Than the Dog? $J$. Climate, 18, 5224-5238.

14. Jin, F.-F., Lin, L., Timmermann, A. \& Zhao, J. (2007). Ensemble Mean Dynamics of the ENSO Recharge Oscillator Under State Dependent Stochastic Forcing. Geophys. Res. Lett., 34, L03807, doi:10.1029/2006GL027372.

15. McPhaden, M.J. (2004). Evolution of the 2002-03 El Niño. Bull. Am. Meteorol. Soc., 85, 677-695.

16. McPhaden, M.J. (2008). Evolution of the 2006-07 El Niño: The Role of Intraseasonal to Interannual Time Scale Dynamics. Adv. Geosci., 14, 219-230.

17. Lyon, B. \& Barnston, A.G. (2005). The Evolution of the Weak El Niño of 2004-2005. U.S. CLIVAR Variations, 3(2), US CLIVAR Office, Washington, DC, 1-4.

18. Larkin, N.K. \& Harrison, D.E. (2005). On the Definition of El Niño and Associated Seasonal Average U.S. Weather Anomalies. Geophys. Res. Lett., 32, L13705, doi:10.1029/2005GL022738.

19. Ashok, K., Behera, S.K., Rao, S.A., Weng, H., \& Yamagata, T. (2007). El Niño Modoki and its Possible Teleconnection. J. Geophys. Res., 112, C11007, doi:10.1029/2006JC003798.

20. Weng, H., Ashok, K., Behera, S.K., Rao, S.A. \& Yamagata, T. (2007). Impacts of Recent El Niño Modoki on Dry/Wet Conditions in the Pacific Rim During Boreal Summer. Climate Dyn., 29, 113-129.
21. Zhang, X. \& McPhaden, M.J. (2006). Wind Stress Variations and Interannual Sea Surface Temperature Anomalies in the Eastern Equatorial Pacific. J. Climate, 19, 226-241.

22. Zhang, X. \& McPhaden, M.J. (2008). Eastern Equatorial Pacific Forcing of ENSO Sea Surface Temperature Anomalies. J. Climate, 21, 6070-6079.

23. Vecchi, G.A. (2006). The Termination of the 1997/98 El Niño. Part II: Mechanisms of Atmospheric Change. J. Climate, 19, 2647-2664.

24. Rienecker, M. \& Co-Authors (2010). "Synthesis and Assimilation Systems - Essential Adjuncts to the Global Ocean Observing System" in these proceedings (Vol. 1), doi:10.5270/OceanObs09.pp.31.

25. Stammer, D. \& Co-Authors (2010). "Ocean Information Provided Through Ensemble Ocean Syntheses" in these proceedings (Vol. 2), doi:10.5270/OceanObs09.cwp.85.

26. Xue, Y. \& Co-Authors (2010). "Ocean State Estimation for Global Ocean Monitoring: ENSO and Beyond ENSO" in these proceedings (Vol. 2), doi:10.5270/OceanObs09.cwp.95.

27. Vidard, A., Anderson, D.L.T. \& Balmaseda, M. (2007). Impact of Ocean Observation Systems on Ocean Analysis and Seasonal Forecasts. Mon. Wea. Rev., 135, 409-429.

28. Balmaseda, M. \& Co-Authors (2010). "Role of the Ocean Observing System in an End-to-End Seasonal Forecasting System" in these proceedings (Vol. 1), doi:10.5270/OceanObs09.pp.03.

29. Balmaseda, M., \& Anderson, D. (2009). Impact of Initialization Strategies and Observations on Seasonal Forecast Skill. Geophys. Res. Lett., 36, L01701, doi:10.1029/2008GL035561.

30. Large, W.G., Danabasoglu, G., McWilliams, J.C., Gent, P.R. \& Bryan, F.O. (2001). Equatorial Circulation of a Global Ocean Climate Model with Anisotropic Horizontal Viscosity. J. Phys. Oceanogr., 31, 518-536.

31. Cronin, M.F., Bond, N.A., Fairall, C.W., \& Weller, R.A. (2006). Surface Cloud Forcing in the East Pacific Stratus Deck/Cold Tongue/ITCZ Complex. J. Climate, 19, 392409.

32. Kelly, K.A., Dickinson, S., McPhaden, M.J. \& Johnson, G.C. (2001). Ocean Currents Evident in Satellite Wind Data. Geophys. Res. Lett., 28, 2469-2472.

33. Dickinson, S., Kelly, K.A., Caruso, M.J. \& McPhaden, M.J. (2001). A Note on Comparisons Between TAO Buoy and NASA Scatterometer Wind Vectors. J. Atmos. Oceanic Technol., 18, 799-806. 
34. Gentemann, C.L., Wentz, F.J., Mears, C.A. \& Smith, D.K. (2004). In Situ Validation of Tropical Rainfall Measuring Mission Microwave Sea Surface Temperatures. J. Geophys. Res., 109, C04021, doi:10.1029/2003JC002092.

35. Kawamura, H., Qin, H. \& Ando, K. (2008). In-Situ Diurnal Sea Surface Temperature Variations and NearSurface Thermal Structure in the Tropical Hot Event of the Indo-Pacific Warm Pool. J. Oceanogr. 64, 847-857.

36. Kara, A.B., Barron, C.N. \& Boyer, T.P. (2009). Evaluations of SST Climatologies in the Tropical Pacific Ocean. J. Geophys. Res., 114, C02021, doi:10.1029/2008JC004909.

37. Reynolds, Richard W., Dudley B. Chelton, 2010: Comparisons of Daily Sea Surface Temperature Analyses for 2007-08. J. Climate, 23, 3545-3562. doi:10.1175/2010JCLI3294.1.

38. Serra, Y.L. \& McPhaden, M.J. (2003). Multiple Time Space Comparisons of ATLAS Buoy Rain Gauge Measurements to TRMM Satellite Precipitation Measurements. J. Appl. Meteorol., 42, 1045-1059.

39. Bowman, K.P. (2005). Comparison of TRMM Precipitation Retrievals With Rain Gauge Data from Ocean Buoys. J. Climate, 18, 178-190.

40. Medavaya, M., Waliser, D.E., Weller, R.A. \& McPhaden, M.J. (2002). Assessing Ocean Buoy Shortwave Observations Using Clear-Sky Model Calculations. J. Geophys. Res., 107(C2), 3014, doi:10.1029/2000JC000558.

41. Pinker, R.T., Wang, H. \& Grodsky, S.A. (2009). How Good Are Ocean Buoy Observations of Radiative Fluxes? Geophys. Res. Lett., 36, L10811, doi:10.1029/2009GL037840.

42. Servain, J., Busalacchi, A.J., McPhaden, M.J., Moura, A.D., Reverdin, G., Vianna, M. \& Zebiak, S.E. (1998). A Pilot Research Moored Array in the Tropical Atlantic (PIRATA). Bull. Am. Meteorol. Soc., 79(10), 20192031.

43. Bourlès, B., Lumpkin, R., McPhaden, M.J., Hernandez, F., Nobre, P., Campos, E., Yu, L., Planton, S., Busalacchi, A., Moura, A.D., Servain, J. \& Trotte, J. (2008). The PIRATA Program: History, Accomplishments, and Future Directions. Bull. Am. Meteor. Soc., 89, 11111125

44. Foltz, G.R., Grodsky, S.A., Carton, J.A. \& McPhaden, M.J. (2003). Seasonal Mixed Layer Heat Budget of the Tropical Atlantic Ocean. J. Geophys. Res., 108(C5), 3146, doi:10.1029/2002JC001584.

45. Foltz, G.R., Grodsky, S.A., Carton, J.A. \& McPhaden, M.J. (2004). Seasonal Salt Budget of the Northwestern Tropical Atlantic Ocean Along $38^{\circ} \mathrm{W}$. J. Geophys. Res., 109(C3), C03052, doi:10.1029/2003JC002111.

46. Yu, L., Jin, X. \& Weller, R.A. (2006). Role of Net Surface Heat Flux in Seasonal Variations of Sea Surface Temperature in the Tropical Atlantic Ocean. J. Climate, 19, 6153-6169.
47. Pailler, K., Bourlès, B. \& Gouriou, Y. (1999). The Barrier Layer in the Western Tropical Atlantic Ocean. Geophys. Res. Lett., 26, 2069-2072.

48. Foltz, G.R. \& McPhaden, M.J. (2008). Impact of Saharan Dust on Tropical North Atlantic SST. J. Climate, 21, 5048-5060.

49. Schott, F.A. \& Coauthors (2003). The Zonal Currents and Transports at $35^{\circ} \mathrm{W}$ in the Tropical Atlantic. Geophys. Res. Lett., 30, 1349, doi:10.1029/2002GL016849.

50. Arhan, M., Tréguier, A.M., Bourlès, B., \& Michel, S. (2006). Diagnosing the Annual Cycle of the Equatorial Undercurrent in the Atlantic Ocean from a General Circulation Model. J. Phys. Oceanogr., 36, 1502-1522.

51. Giarolla, E., Nobre, P., Malagutti, M. \& Pezzi, P. (2005). The Atlantic Equatorial Undercurrent: PIRATA Observations and Simulations with GFDL Modular Ocean Model at CPTEC. Geophys. Res. Lett., 32, L10617, doi:10.1029/2004GL022206.

52. Foltz, G.R. \& McPhaden, M.J. (2006). Unusually Warm Sea Surface Temperatures in the Tropical North Atlantic During 2005. Geophys. Res. Lett., 33, L19703, doi:10.1029/2006GL027394.

53. Vecchi, G.A., Swanson, K.L. \& Soden, B.J. (2008). Whither Hurricane Activity? Science, 332, 687-689.

54. Chang, P., Ji, L. \& Saravanan, R. (2001). A Hybrid Coupled Model Study of Tropical Atlantic Variability. $J$. Climate, 14, 361-390.

55. Lau, K.M. \& Kim, J.M. (2007a). How Nature Foiled the 2006 Hurricane Forecasts. Eos, Trans. Am. Geophys. Union, 88, 105-107.

56. Foltz, G.R. \& McPhaden, M.J. (2009). Impact of Barrier Layer Thickness on SST in the Central Tropical North Atlantic. J. Climate, 22, 285-299.

57. Foltz, G.R. \& McPhaden, M.J. (2008). Trends in Saharan dust and tropical Atlantic climate during 1980-2006. Geophys. Res. Lett., 35, L20706, doi:10.1029/2008GL035042.

58. Okumura, Y. \& Xie, S.P. (2006). Some Overlooked Features of Tropical Atlantic Climate Leading to a New Niño-Like Phenomenon. J. Climate, 19, 5859-5874.

59. Stockdale, T.N., Balmaseda, M.A. \& Vidard, A. (2006). Tropical Atlantic SST Prediction with Coupled OceanAtmosphere GCMs. J. Climate, 19, 6047-6061.

60. Chang, P. and Coauthors (2006). Climate Fluctuations of Tropical Coupled Systems - The Role of Ocean Dynamics. J. Climate, 19, 5122-5174.

61. Enfield, D.B. \& Mayer, D.A. (1997). Tropical Atlantic SST Variability and its Relation to El Niño-Southern Oscillation. J. Geophys. Res., 102, 929-945.

62. Czaja, A., van der Vaart, P. \& Marshall, J., (2002). A Diagnostic Study of the Role of Remote Forcing in Tropical Atlantic Variability. J. Climate, 15, 3280-3290. 
63. Davey, M.K., et al. (2002). STOIC: A Study of Coupled Model Climatology and Variability in Tropical Ocean Regions. Clim. Dyn., 18, 403-420.

64. Segschneider, J., Balmaseda, M. \& Anderson, D.L.T. (2000). Anomalous Temperature and Salinity Variations in the Tropical Atlantic: Possible Causes and Implications for the Use of Altimeter Data. Geophys. Res. Lett., 27, 2281-2284.

65. Yu, L. \& Weller, R.A. (2007). Objectively Analyzed AirSea Heat Fluxes for the Global Ice-Free Oceans (19812005). Bull. Am. Meteorol. Soc., 88, 527-539.

66. McPhaden, M.J., Meyers, G., Ando, K., Masumoto, Y., Murty, V.S.N., Ravichandran, M., Syamsudin, F., Vialard, J., Yu, L. \& Yu, W. (2009). RAMA: The Research Moored Array for African-Asian-Australian Monsoon Analysis and Prediction. Bull. Am. Meteorol. Soc., 90, 459-480.

67. Meyers, G. \& Boscolo, R. (2006). The Indian Ocean Observing System (IndOOS). CLIVAR Exchanges, 11(4), International CLIVAR Project Office, Southampton, UK, 2-3.

68. Masumoto, Y. \& Co-Authors (2010). "Observing Systems in the Indian Ocean" in these proceedings (Vol. 2), doi:10.5270/OceanObs09.cwp.60.

69. Sengupta, D., Senan, R., Murty, V.S.N. \& Fernando, V. (2004). A Biweekly Mode in the Equatorial Indian Ocean. J. Geophys. Res., 109, C10003, doi:10.1029/2004JC002329.

70. Masumoto, Y., Hase, H., Kuroda, Y., Matsuura, H. \& Takeuchi, K. (2005). Intraseasonal Variability in the Upper Layer Currents Observed in the Eastern Equatorial Indian Ocean. Geophys. Res. Lett., 32, L02607, doi:10.1029/2004GL021896.

71. Hase, H., Masumoto, Y., Kuroda, Y. \& Mizuno, K. (2008). Semiannual Variability in Temperature and Salinity Observed by Triangle Trans-Ocean Buoy Network (TRITON) Buoys in the Eastern Tropical Indian Ocean, J. Geophys. Res., 113, C01016, doi:10.1029/2006JC004026.

72. Nagura, M. \& McPhaden, M.J. (2008). The Dynamics of Zonal Current Variations in the Central Equatorial Indian Ocean. Geophys. Res. Lett., 35, K23603, doi:10.1029/2008GL035961.

73. Murty, V.S.N., Sarma, M.S.S., Suryanarayana, A., Sengupta, D., Unnikrishnan, A.S., Fernando, V., Almeida, A., Khalap, S., Sardar, A., Somasundar, K. \& Ravichandran, M. (2006). Indian Moorings: Deep-Sea Current Meter Moorings in the Eastern Equatorial Indian Ocean. CLIVAR Exchanges, 11(4), International CLIVAR Project Office, Southampton, UK, 5-8.

74. Ogata, T., Sasaki, H., Murty, V.S.N., Sarma, M.S.S. \& Masumoto Y. (2008). Intraseasonal Meridional Current Variability in the Eastern Equatorial Indian Ocean, $J$. Geophys. Res., 113, C07037, doi:10.1029/2007JC004331.
75. Horii, T., Hase, H., Ueki, I. \& Masumoto, Y. (2008). Oceanic Precondition and Evolution of the 2006 Indian Ocean Dipole, Geophys. Res. Lett., 35, L03607, doi:10.1029/2007GL032464.

76. Horii, T., Masumoto, Y., Ueki, I., Hase, H. \& Mizuno, K. (2009). Mixed Layer Temperature Balance in the Eastern Indian Ocean During the 2006 Indian Ocean Dipole. J. Geophys. Res., 114, C07011, doi:10.1029/2008JC005180.

77. Vialard, J., Foltz, G., McPhaden, M.J., Duvel, J.P. \& de Boyer Montégut, C. (2008). Strong Indian Ocean Sea Surface Temperature Signals Associated With the Madden-Julian Oscillation in Late 2007 and Early 2008. Geophys. Res. Lett., 35, L19608, doi:10.1029/2008GL035238.

78. McPhaden, M.J., Foltz, G.R., Lee, T., Murty, V.S.N., Ravichandran, M., Vecchi, G.A., Vialard, J., Wiggert, J.D., Yu, L. (2009). Ocean-Atmosphere Interactions During Cyclone Nargis. EOS, Trans. Am. Geophys. Union, 90, 53-54.

79. Luo, J.-J., Behera, S., Masumoto, Y., Sakuma, H. \& Yamagata, T. (2008). Successful Prediction of the Consecutive IOD in 2006 and 2007. Geophys. Res. Lett., 35, L14S02, doi:10.1029/2007GL032793.

80. Johnson, G.C., McPhaden, M.J. \& Firing, E. (2001). Equatorial Pacific Ocean Horizontal Velocity, Divergence, and Upwelling. J. Phys. Oceanogr., 31, 839-849.

81. Cronin, M.F., Bond, N., Fairall, C., Hare, J., McPhaden, M.J. \& Weller, R.A. (2002). Enhanced Oceanic and Atmospheric Monitoring for the Eastern Pacific. Eos Trans. AGU, 83, 205.

82. Feely, R.A., Takahashi, T., Wanninkhof, R., McPhaden, M.J., Cosca, C.E., Sutherland, S.C. \& Carr, M.-E. (2006). Decadal Variability of the Air-Sea $\mathrm{CO}_{2}$ Fluxes in the Equatorial Pacific Ocean. J. Geophys. Res., 111, C08S90, doi:10.1029/2005JC003129.

83. Chavez, F.P., Strutton, P.G., Friederich, G.E., Feely, R.A., Feldman, G.C. Foley, D.G., \& McPhaden, M.J. (1999). Biological and Chemical Response of the Equatorial Pacific Ocean to the 1997-1998 El Niño. Science, 286, 2126-2131.

84. McPhaden, M.J., Cronin, M.F. \& McClurg, D.C. (2008). Meridional Structure of the Surface Mixed Layer Temperature Balance on Seasonal Time Scales in the Eastern Tropical Pacific. J. Climate, 21, 3240-3260.

85. Schott, F.A. \& Coauthors (2004). A White Paper on "Tropical Atlantic Climate Experiment (TACE)." [Available online at http://www.usclivar.org/Meeting Files/SSC11/TACE_whitepaper_draft2_text.pdf .

86. Redelsperger, J.L., Thorncroft, C.D., Diedhiou, A., Lebel, T., Parker, D.J. \& Polcher, J. (2006). African Monsoon Multidisciplinary Analysis: An International Research Project and Field Campaign. Bull. Am. Meteor. Soc., 87, 1739-1746. 
87. Bourlès, B., Brandt, P., Caniaux, G., Dengler, M., Gouriou, Y., Key, E., Lumpkin, R., Marin, F., Molinari, R.L. \& Schmid, C. (2007). African Monsoon Multidisciplinary Analysis (AMMA): Special Measurements in the Tropical Atlantic, CLIVAR Exchanges Letters, 41 (Vol. 12, No. 2), 7-9.

88. Yoneyama, K., et al. (2008). MISMO Field Experiment in the Tropical Indian Ocean. Bull. Am. Meteor. Soc., 89, 1889-1903.

89. Vialard, J., Duvel, J.P., McPhaden, M., Bouruet-Aubertot, P., Ward, B., Key, E., Bourras, D., Weller, R., Minnett, P., Weill, A., Cassou, C., Eymard, L., Fristedt, T., Basdevant, C., Dandoneau, Y., Duteil, O., Izumo, T., de Boyer Montégut, C., Masson, S. \& Marsac, F. (2009). Cirene: Air-Sea Interactions in the Seychelles-Chagos Thermocline Ridge Region. Bull. Am. Meteorol. Soc., 90, 45-61.

90. Lubick, N. (2009). Damaged Buoys Blur El Niño Forecasts. Nature, 461, 455.

91. NOAA (2009). Buoy Recapitalization Strategic Plan: Review of Current Processes. National Oceanic and Atmospheric Administration, Silver Spring, MD, 252 pp.

92. GCOS (2003). The Second Adequacy Report of the Global Observing Systems for Climate in Support of UNFCCC. Publication GCOS-82, World Meteorological Organization, Geneva, Switzerland, 74 pp.

93. Meinen, C.S. \& McPhaden, M.J. (2000). Observations of Warm Water Volume Changes in the Equatorial Pacific and Their Relationship to El Niño and La Niña. $J$. Climate, 13, 3551-3559. 